\title{
Lactococcus lactis
}

National Cancer Institute

\section{Source}

National Cancer Institute. Lactococcus lactis. NCI Thesaurus. Code C86485.

A species of Gram positive, cocci shaped, lactic acid bacteria assigned to the phylum Firmicutes. This species is nonmotile, catalase negative, nonsporulating and produces lactic acid from lactose fermentation. L lactis may be an opportunistic pathogen in humans and animals. Most significantly this microorganism is used commercially in the production of buttermilk and cheese. 